\title{
Characterization of submicron organic particles in Beijing during summertime: comparison between SP-AMS and HR-AMS
}

\author{
Junfeng Wang ${ }^{1,2}$, Jianhuai Ye², Dantong Liu ${ }^{3}$, Yangzhou $\mathrm{Wu}^{3}$, Jian $\mathrm{Zhao}^{4}$, Weiqi Xu${ }^{4}$, Conghui Xie ${ }^{4}$, Fuzhen Shen ${ }^{1}$, \\ Jie Zhang ${ }^{5}$, Paul E. Ohno ${ }^{2}$, Yiming Qin ${ }^{2}$, Xiuyong Zhao ${ }^{6}$, Scot T. Martin ${ }^{2}$, Alex K. Y. Lee ${ }^{7}$, Pingqing Fu ${ }^{8}$, \\ Daniel J. Jacob ${ }^{2}$, Qi Zhang ${ }^{9}$, Yele Sun ${ }^{4}$, Mindong Chen ${ }^{1}$, and Xinlei Ge ${ }^{1}$ \\ ${ }^{1}$ Jiangsu Key Laboratory of Atmospheric Environment Monitoring and Pollution Control, Collaborative Innovation Center of \\ Atmospheric Environment and Equipment Technology, School of Environmental Science and Engineering, Nanjing \\ University of Information Science and Technology, Nanjing, China \\ ${ }^{2}$ School of Engineering and Applied Sciences, Harvard University, Cambridge, MA, USA \\ ${ }^{3}$ Department of Atmospheric Sciences, School of Earth Sciences, Zhejiang University, Hangzhou, China \\ ${ }^{4}$ State Key Laboratory of Atmospheric Boundary Layer Physics and Atmospheric Chemistry, Institute of Atmospheric \\ Physics, Chinese Academy of Sciences, Beijing, China \\ ${ }^{5}$ Department of Atmospheric Science, Colorado State University, Fort Collins, CO, USA \\ ${ }^{6}$ State Environmental Protection Key Laboratory of Atmospheric Physical Modeling and Pollution Control, State Power \\ Environmental Protection Research Institute, Nanjing, China \\ ${ }^{7}$ Department of Civil and Environmental Engineering, National University of Singapore, Singapore \\ ${ }^{8}$ Institute of Surface-Earth System Science, Tianjin University, Tianjin, China \\ ${ }^{9}$ Department of Environmental Toxicology, University of California Davis, Davis, CA, USA
}

Correspondence: Xinlei Ge (caxinra@163.com)

Received: 22 July 2020 - Discussion started: 30 July 2020

Revised: 6 October 2020 - Accepted: 10 October 2020 - Published: 20 November 2020

\begin{abstract}
Black carbon (BC) particles in Beijing summer haze play an important role in the regional radiation balance and related environmental processes. Understanding the factors that lead to variability of the impacts of $\mathrm{BC}$ remains limited. Here, we present observations by a soot-particle aerosol mass spectrometer (SP-AMS) of BC-containing submicron particulate matter $\left(\mathrm{BC}-\mathrm{PM}_{1}\right)$ in Beijing, China, during summer 2017. These observations were compared to concurrently measured total non-refractory submicron particulate matter $\left(\mathrm{NR}-\mathrm{PM}_{1}\right)$ by a high-resolution aerosol mass spectrometer (HR-AMS). Distinct properties were observed between $\mathrm{NR}-\mathrm{PM}_{1}$ and $\mathrm{BC}-\mathrm{PM}_{1}$ relevant to organic aerosol (OA) composition. Hydrocarbon-like OA (HOA) in $\mathrm{BC}-\mathrm{PM}_{1}$ was found to be up to 2 -fold higher than that in $\mathrm{NR}-\mathrm{PM}_{1}$ in fresh vehicle emissions, suggesting that a part of $\mathrm{HOA}$ in $\mathrm{BC}-\mathrm{PM}_{1}$ may be overestimated, likely due to the change of collection efficiency of SP-AMS. Cooking-related $\mathrm{OA}$ was only identified in $\mathrm{NR}-\mathrm{PM}_{1}$, whereas aged biomass burning OA (A-BBOA) was a unique factor only identified
\end{abstract}

in $\mathrm{BC}-\mathrm{PM}_{1}$. The A-BBOA was linked to heavily coated $\mathrm{BC}$, which may lead to enhancement of the light absorption ability of BC by a factor of 2 via the "lensing effect". Moreoxidized oxygenated $\mathrm{OA}$ identified in BC-containing particles was found to be slightly different from that observed by HR-AMS, mainly due to the influence of A-BBOA. Overall, these findings highlight that $\mathrm{BC}$ in urban Beijing is partially of agricultural fire origin and that a unique biomass-burningrelated $\mathrm{OA}$ associated with $\mathrm{BC}$ may be ubiquitous in aged $\mathrm{BC}-\mathrm{PM}_{1}$, and this OA may play a role in affecting air quality and climate that has not previously been fully considered.

\section{Introduction}

Black carbon (BC) is an important component of atmospheric aerosol that exerts negative effects on the regional radiation balance (Bond et al., 2013) and human health (Janssen et al., 2012). It absorbs solar radiation, leading to 
direct atmospheric heating (Ramanathan and Carmichael, 2008). Indirectly, BC-containing particles (BCc) can also serve as cloud condensation nuclei upon mixing with hydrophilic species (e.g., sulfate), resulting in changes in cloud properties (Wu et al., 2019). Inhalation of BC is associated with adverse health impacts such as respiratory diseases and birth defects (Janssen et al., 2012).

$\mathrm{BC}$ particles are released into the atmosphere directly and usually mixed with non-BC materials (e.g., inorganic and organic) from incomplete fuel combustion and open fires (Ramanathan and Carmichael, 2008; Bond et al., 2013; Chen et al., 2013). Non-BC species also can coat primary BCc in the atmosphere through condensation and/or coagulation processes (Lee et al., 2017). These atmospheric processes gradually alter the mixing state and the morphology of BCc, e.g., from an externally mixed fractal structure (Buseck et al., 2014) into an internally mixed "core-shell" structure (China et al., 2015). These alterations can enhance the light absorption capacity of the $\mathrm{BC}$ core via the "lensing effect" due to the increased light absorption cross-section as a result of the enhanced coating thickness (Saleh et al., 2015; Cappa et al., 2012). Additionally, the chemical constituents of BCc may dynamically change during aging processes, which also leads to changes in the light absorption capacity of the particles (Wang et al., 2017, 2019). Because these physical and chemical processes of both organic and inorganic species inside BCc continuously alter particle properties throughout the lifetime of the particles, great uncertainty remains in quantifying the light absorption ability of $\mathrm{BC}$ (Liu et al., 2018 , 2019). Understanding the relationship of mixing state and chemical composition with the light absorption properties of $\mathrm{BCc}$, as well as its spatiotemporal distribution, is of importance to accurately evaluate the impacts of $\mathrm{BC}$ on regional air quality.

Aerodyne high-resolution aerosol mass spectrometry (Canagaratna et al., 2007) has been widely applied in field studies to investigate the chemically resolved composition of non-refractory submicron particulate matter $\left(\mathrm{NR}-\mathrm{PM}_{1}\right.$, species that vaporize at temperature $<600^{\circ} \mathrm{C}$ ) ( $\mathrm{Li}$ et al., 2015; Lee et al., 2013; Sun et al., 2012, 2014; Ge et al., 2012a, b; Xu et al., 2019b). However, the working temperature of the standard high-resolution aerosol mass spectrometer (HR-AMS) tungsten vaporizer $\left(600^{\circ} \mathrm{C}\right)$ is not sufficient to vaporize refractory species such as $\mathrm{BC}$. To overcome this limitation, soot-particle aerosol mass spectrometry is developed (Onasch et al., 2012). In addition to the standard tungsten vaporizer, the soot-particle aerosol mass spectrometer (SP-AMS) is equipped with a laser vaporizer (with a wavelength of $1064 \mathrm{~nm}$ ) which selectively heats $\mathrm{BC}$ (core), together with the non-BC species mixed with it (Wang et al., 2016). This novel technique makes it possible to compare the compositions of submicron $\mathrm{BCc}\left(\mathrm{BC}-\mathrm{PM}_{1}\right)$ and $\mathrm{NR}-\mathrm{PM}_{1}$, allowing a more accurate assessment of the impacts of $\mathrm{BC}$. However, a question is whether the ion fragments of organic species ionized by the $70 \mathrm{eV}$ electron impact of SP-AMS and
HR-AMS are the same in terms of different thermal schemes. It has been reported that the mass spectra of $\mathrm{NR}-\mathrm{PM}_{1}$ organics have high $m / z 44$ (mainly $\mathrm{CO}_{2}^{+}$) signal, while the mass spectra of BC-related organics have high $m / z 43\left(\mathrm{C}_{3} \mathrm{H}_{7}^{+}\right.$and $\mathrm{C}_{2} \mathrm{H}_{3} \mathrm{O}^{+}$) signal. The reason for this is that the SP-AMS provides vaporization of the $\mathrm{BC}-\mathrm{PM}_{1}$ at lower temperatures compared to the standard tungsten vaporizer of the HR-AMS, resulting in less overall fragmentation and therefore less $\mathrm{CO}_{2}^{+}$production; in addition, the lower fragmentation also causes the presence of more ion fragments at $m / z>100 \mathrm{amu}$ in the SP-AMS mass spectra compared to that of HR-AMS (Canagaratna et al., 2015b; Massoli et al., 2015). Nevertheless, the quantification of $\mathrm{BC}-\mathrm{PM}_{1}$ organic aerosol (OA) factors identified from positive matrix factorization (PMF) has been reported that were not significantly affected by the differences of mass spectra between HR-AMS and SP-AMS (Lee et al., 2017; Massoli et al., 2015).

To date, there have only been a few studies that have compared the differences of species in $\mathrm{BC}-\mathrm{PM}_{1}$ and $\mathrm{NR}-\mathrm{PM}_{1}$ (Lee et al., 2017; Collier et al., 2015; Massoli et al., 2015). Lee et al. found that cooking-related organic aerosol (COA) may externally mix with $\mathrm{BC}$ in summertime in California (Lee et al., 2017). The COA factor was identified in $\mathrm{NR}-\mathrm{PM}_{1}$ organic aerosol (OA) but not in the BC-related OA. Wang et al. (2017) found that transported biomass burning organic aerosol could thickly coat BC in the central Tibetan Plateau and significantly enhance the light absorption capacity of BC cores. Interestingly, the transported biomass burning organic aerosol was not resolved in $\mathrm{NR}-\mathrm{PM}_{1} \mathrm{OA}$ particles from concurrent HR-AMS measurements (Xu et al., 2018). These studies suggest that BC-related OA may undergo different atmospheric processes compared to aerosols that do not contain BC.

Beijing is a megacity known for high particulate matter (PM) concentrations. $\mathrm{BC}-\mathrm{PM}_{1}$ during haze events of summertime in Beijing may have distinct sources and properties from other locations in the world. As a part of the UKChina Air Pollution and Human Health (APHH) project summer campaign (Shi et al., 2019; Chen et al., 2020a, b), in this study, we focus on the differences of individual species between $\mathrm{BC}-\mathrm{PM}_{1}$ and $\mathrm{NR}-\mathrm{PM}_{1}$ regarding their chemical composition, mass loadings, sources, and formation pathways in summertime in urban Beijing. Results from this study provide a better understanding of the formation mechanism of OA in Beijing haze and valuable insights into their impacts on air quality.

\section{Experiments}

\subsection{Sampling site and period}

The observations were conducted at a rooftop laboratory (8 ma.g.l.) in the Tower Division of the Institute of Atmospheric Physics (IAP), Chinese Academy of Sciences (CAS), 
in urban Beijing $\left(39^{\circ} 58^{\prime} \mathrm{N}, 116^{\circ} 22^{\prime} \mathrm{E}\right)$, China, from 4 to 29 June 2017. This site has been reported multiple times to be a typical urban observation location (Xie et al., 2019a, b; Liu et al., 2019; Wang et al., 2019; Qiu et al., 2019; Xu et al., 2019a). The site is located around the North 3rd Ring Road of Beijing. A highway is approximately $360 \mathrm{~m}$ to the east, and a lot of restaurants (e.g., Sichuan-style and BBQ) are within $100 \mathrm{~m}$ on the north side.

\subsection{Instrumentation}

Two Aerodyne aerosol mass spectrometers (AMSs), a laseronly soot-particle AMS (SP-AMS) and a high-resolution time-of-flight AMS (HR-AMS), were deployed to measure chemical compositions and size distributions of $\mathrm{BC}-\mathrm{PM}_{1}$ and $\mathrm{NR}-\mathrm{PM}_{1}$, respectively. Three types of species were measured during the campaign: $\mathrm{NR}-\mathrm{PM}_{1}$, including nonrefractory species that do not mix with BC (Type I) and non-refractory species that mixed with BC (Type II), as well as $\mathrm{BC}-\mathrm{PM}_{1}$ (BC core and both refractory and nonrefractory species that coat the core) (Type III). NR-PM can be quickly vaporized by the $600{ }^{\circ} \mathrm{C}$ tungsten vaporizer of HR-AMS and be detected. The SP-AMS used here was equipped only with the Nd:YAG intra-cavity infrared laser (1064 nm) (tungsten vaporizer was physically removed); it can selectively detect BC-containing particles only, which include Type II and Type III species. A shared $\mathrm{PM}_{2.5}$ cyclone inlet (Model URG-2000-30ED) with a 3 Lpm flow rate and a diffusion dryer were used prior to the sampling. Detailed information on the operation of HR-AMS and SP-AMS during the sampling campaign can be found in previous literature (Xie et al., 2019a; Xu et al., 2019b). Details of tuning, calibration, and configurations of the two AMS instruments can be seen in our previous papers (Wang et al., 2019; Xu et al., 2019a, b). The two AMSs were operated under the V mode which is favorable for mass quantification with a time resolution of 5 min. Mixing ratios of $\mathrm{O}_{3}$ and $\mathrm{NO}_{2}$ (Thermo Fisher Scientific, model $49 i$ and model 42C) were measured in parallel simultaneously. Vertical meteorological parameters, including temperature $(T)$ and relative humidity $(\mathrm{RH})$, were measured from the IAP $325 \mathrm{~m}$ meteorological tower.

\subsection{Data analysis}

AMS data analysis was performed using Squirrel 1.57 and Pika 1.16I based on Igor Pro 6.37 (WaveMetrics Corp.). The measurement of filtered air was performed for $24 \mathrm{~h}$ before the start of the campaign to determine the detection limits of various aerosol species and to adjust the fragmentation table. The relative ionization efficiency (RIE) of BC was calibrated with Regal Black (RB, REGAL 400R pigment black, Cabot Corp.). The average ratio of $\mathrm{C}_{1}^{+}$to $\mathrm{C}_{3}^{+}$ionized from pure $\mathrm{BC}$ (RB) was determined to be 0.53 , which minimizes the influence of non-refractory organics on $\mathrm{C}_{1}^{+}$. The RIE of BC was determined to be 0.17 based on calibrations performed be- fore, in the middle, and at the end of the campaign. RIEs of $\mathrm{NO}_{3}^{-}, \mathrm{SO}_{4}^{2-}, \mathrm{NH}_{4}^{+}$were determined to be $1.1,0.82$, and 3.82 , respectively, and default values of 1.3 and 1.4 for RIEs of cholride and OA, respectively, were applied (Canagaratna et al., 2007). Consistent with $\mathrm{BC}-\mathrm{PM}_{1}$ measurements in previous studies, the RIEs' calibration of $\mathrm{NO}_{3}^{-}, \mathrm{SO}_{4}^{2-}$, and $\mathrm{NH}_{4}^{+}$was performed before the tungsten vaporizer was removed, by assuming those RIEs remain unchanged throughout the campaign (Wang et al., 2017). Polystyrene latex (PSL) spheres (100-700 nm) (Duke Scientific Corp., Palo Alto, CA) were used to calibrate the particle size distribution before the campaign. A collection efficiency (CE) of 0.5 was applied for both HR-AMS and SP-AMS in this study. It should be noted that the $\mathrm{BC}$ quantification will not be affected by particle bouncing without the tungsten vaporizer, which could affect the CE in the standard HR-AMS measurements (Canagaratna et al., 2007). However, the CE will be governed by the overlap of the particle beam and laser beam (Lee et al., 2017; Massoli et al., 2015; Willis et al., 2014). Both HR-AMS- and SP-AMS-resolved mass concentrations of $\mathrm{NR}-\mathrm{PM}_{1}$ and $\mathrm{BC}$ were calculated based on $\mathrm{V}$-mode highresolution fitting. Due to different vaporization schemes between the HR-AMS and SP-AMS, mass spectra from these two instruments, even for the same population of aerosols, are not entirely the same. Because laser-only SP-AMS generally results in less overall fragmentation, its mass profile may contain more large $m / z$ fragments and fewer small $m / z$ fragments compared to that of HR-AMS (Massoli et al., 2015). In addition, the elemental ratios of organics reported here, i.e., oxygen-to-carbon and hydrogen-to-carbon ratios $(\mathrm{O} / \mathrm{C}$ and $\mathrm{H} / \mathrm{C}$ ), were calculated based on the "Improved-Ambient" (IA) method (Canagaratna et al., 2015a). (Scaling factors of 1.10 for $\mathrm{H}: \mathrm{C}$ and 0.86 for $\mathrm{O}: \mathrm{C}$ were applied for elemental ratios calculated from SP-AMS data.)

Positive matrix factorization (PMF) (Paatero and Tapper, 1994) was performed on the high-resolution organic mass spectral matrix of both $\mathrm{NR}-\mathrm{PM}_{1}$ and $\mathrm{BC}-\mathrm{PM}_{1}$ (e.g., $\mathrm{BC}$ $\left(\mathrm{C}_{x}^{+}\right)$, and species associated with $\left.\mathrm{BC}\right)$ across $m / z$ 12-120 using the PMF Evaluation Tool written in Igor (Ulbrich et al., 2009), following standard procedure (Zhang et al., 2011). Four types of organic aerosol (OA) from total NR-PM 1 (see our previous paper) (Xu et al., 2019b) and five OA factors from $\mathrm{BC}-\mathrm{PM}_{1}$ were identified. $\mathrm{C}_{x}^{+}$was involved in the calculation of elemental ratios (e.g, $\mathrm{O} / \mathrm{C}$ and $\mathrm{H} / \mathrm{C}$ ) of PMF OA factors. All data presented in this paper were averaged hourly and are presented at local time (Beijing time, UTC +8 ).

\section{Results and discussion}

\subsection{Overview of observations}

Figure 1 shows the temporal variations of selected chemical species during the campaign. Information for other variables is provided in the Supplement. The two cases labeled 


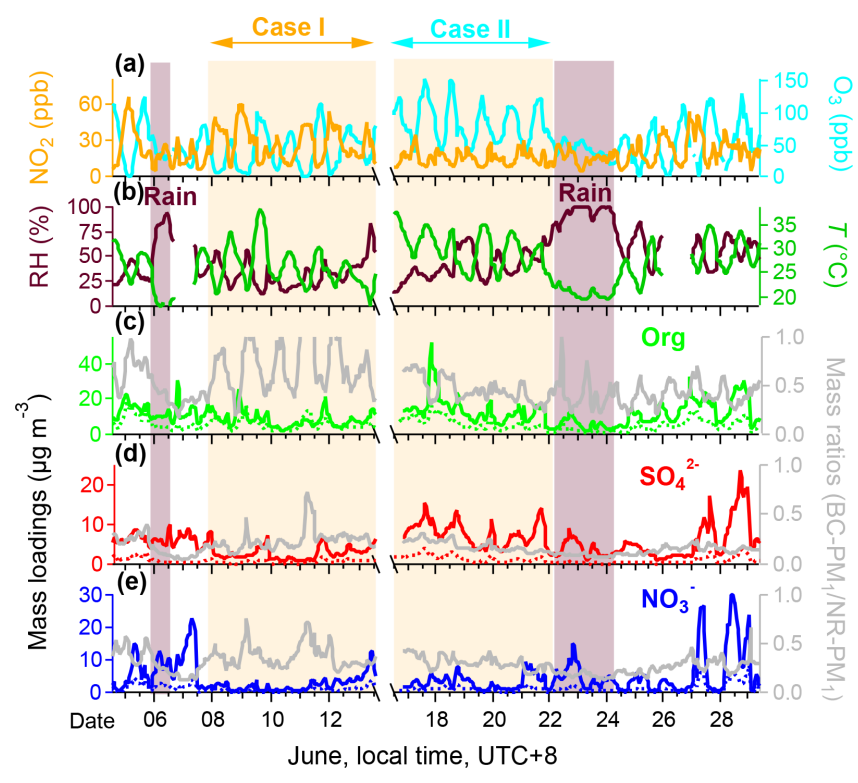

Figure 1. Temporal variations of selected chemical species measured in Beijing on 4-29 June 2017. (a) Mixing ratios of nitrogen dioxide $\left(\mathrm{NO}_{2}\right)$ and ozone $\left(\mathrm{O}_{3}\right)$. (b) $15 \mathrm{~m}$ relative humidity $(\mathrm{RH})$ and temperature $(T)$. (c-e) On the left are the mass loadings of organic (Org), sulfate $\left(\mathrm{SO}_{4}^{2-}\right)$ and nitrate $\left(\mathrm{NO}_{3}^{-}\right)$measured by HRAMS and SP-AMS, and on the right are the mass ratios of individual $\mathrm{BC}-\mathrm{PM}_{1}$ species to $\mathrm{NR}-\mathrm{PM}_{1}$ species (e.g., $\mathrm{BC}-\mathrm{PM}_{1}$ Org to $\mathrm{NR}-\mathrm{PM}_{1} \mathrm{Org}$ ). The NR-PM $\mathrm{P}_{1}$ species measured by HR-AMS is shown by the solid line, and the $\mathrm{BC}-\mathrm{PM}_{1}$ species measured by SP-AMS is shown by the dotted line. The shaded areas are raining periods. The observation period is divided into two cases according to the mixing ratio of nitrogen $\mathrm{NO}_{2}$, Case I and Case II, which represent high $\mathrm{NO}_{2}$ and low $\mathrm{NO}_{2}$ mixing ratios, respectively.

in Fig. 1 are of interest. Case I (8-13 June) was characterized with high $\mathrm{NO}_{2}$ concentrations (average $26.7 \pm 13.5 \mathrm{ppb}$, Table $\mathrm{S} 1$ in the Supplement) and relatively low $\mathrm{O}_{3}$ concentrations $(41.7 \pm 30.0 \mathrm{ppb})$, with an $\mathrm{NO}_{2}$-to- $\mathrm{O}_{3}$ ratio of 0.64. Case II (17-22 June) was featured by low $\mathrm{NO}_{2}$ $(14.9 \pm 5.9 \mathrm{ppb})$ and high $\mathrm{O}_{3}(84.6 \pm 30.6 \mathrm{ppb})$ concentrations, with an $\mathrm{NO}_{2}$-to- $\mathrm{O}_{3}$ ratio of 0.18 . Unlike winter Beijing haze pollution, $\mathrm{RH}$ remained at a relatively low level $(36.5 \% \pm 15.3 \%)$, which is not expected to play a significant role in OA formation during the campaign (Figs. 1b and S1 in the Supplement). In contrast, a strong correlation has been observed between temperature and $\mathrm{O}_{3}\left(r^{2}=0.53\right)$. The temperature was higher on average in Case II $\left(29.8 \pm 3.8^{\circ} \mathrm{C}\right)$ than in Case $\mathrm{I}\left(26.1 \pm 4.1^{\circ} \mathrm{C}\right)$.

The mass concentrations and mass ratios of organic (Org), sulfate $\left(\mathrm{SO}_{4}^{2-}\right)$, and nitrate $\left(\mathrm{NO}_{3}^{-}\right)$in $\mathrm{NR}-\mathrm{PM}_{1}$ (in solid line) and $\mathrm{BC}-\mathrm{PM}_{1}$ (in dotted line) are shown in Fig. 1c and e. High correlations were observed between $\mathrm{BC}-\mathrm{PM}_{1}$ and $\mathrm{NR}-\mathrm{PM}_{1}$ measurements for $\mathrm{SO}_{4}^{2-}\left(r^{2}=0.70\right)$ and $\mathrm{NO}_{3}^{-}$ $\left(r^{2}=0.86\right)$ but not for Org $\left(r^{2}=0.49\right)$. This result suggests that $\mathrm{BC}-\mathrm{PM}_{1}$ Org has distinct sources or formation pathways from $\mathrm{NR}-\mathrm{PM}_{1}$ Org. Comparing two cases, the average mass ratios of $\mathrm{BC}-\mathrm{PM}_{1}$ to $\mathrm{NR}-\mathrm{PM}_{1}$ for $\mathrm{SO}_{4}^{2-}$ and $\mathrm{NO}_{3}^{-}$ in Case I $(0.24 \pm 0.11$ and $0.37 \pm 0.12)$ were close to those in Case II $(0.19 \pm 0.06$ and $0.31 \pm 0.07)$. However, ratios of $\mathrm{BC}-\mathrm{PM}_{1}$ to $\mathrm{NR}-\mathrm{PM}_{1}$ for Org were a factor of 1.61 greater for Case I $(0.74 \pm 0.32)$ compared to Case II $(0.46 \pm 0.13)$. During the nighttime, this ratio increases to almost unity in Case I. Additionally, BC concentration in Case I (average $2.6 \pm 1.6 \mu \mathrm{g} \mathrm{m}^{-3}$ ) was 1.5 -fold higher than in Case II (average $1.7 \pm 0.8 \mu \mathrm{g} \mathrm{m}^{-3}$ ). The implication is that the organic is mostly associated with BC and likely comprised of freshly emitted compounds in Case I. This is also evident by the moderate correlation between $\mathrm{NO}_{2}$ and $\mathrm{BC}-\mathrm{PM}_{1} \mathrm{Org}$ $\left(r^{2}=0.42\right)$ in Case I. On the other hand, the lower Org ratio in Case II with higher $\mathrm{O}_{3}$ concentrations indicates greater oxidation and secondary processes in non-BC particles.

\subsection{Source apportionment of $\mathrm{BC}-\mathrm{PM}_{1} \mathrm{OA}$}

To further investigate the differences between organics in $\mathrm{NR}-\mathrm{PM}_{1}$ and $\mathrm{BC}-\mathrm{PM}_{1}$, the comparison of PMF OA factors between $\mathrm{NR}-\mathrm{PM}_{1}$ and $\mathrm{BC}-\mathrm{PM}_{1}$ Org is necessary. Four factors were identified from PMF analysis of the NR-PM Org matrix, including hydrocarbon-related OA (HOA), cooking OA (COA), less-oxidized oxygenated OA (LO-OOA), and more-oxidized oxygenated OA (MO-OOA). Details of the $\mathrm{NR}-\mathrm{PM}_{1} \mathrm{PMF}$ analysis can be found in our previous study (Xu et al., 2019b). Here we only present the $\mathrm{PMF}$ results of the SP-AMS measured $\mathrm{BC}-\mathrm{PM}_{1}$ Org. As shown in Fig. 2, five factors were resolved by PMF including a HOA, a less-oxidized OOA (OOA1), and three moreoxidized OOA factors which were recombined into one OOA factor $(\mathrm{MO}-\mathrm{OOA}=$ aged biomass burning organic aerosol $(\mathrm{A}-\mathrm{BBOA})+\mathrm{OOA} 2+\mathrm{OOA} 3)$. Diagnostic plots of this PMF solution are presented in Fig. S2 in the Supplement.

HOA consists of a series of hydrocarbon fragments $\left(\mathrm{C}_{x} \mathrm{H}_{y}^{+}\right)$in its mass spectrum (Fig. 2f), thus having a low $\mathrm{O} / \mathrm{C}$ ratio (0.13) but a high $\mathrm{H} / \mathrm{C}$ ratio (1.62). It has a $r^{2}$ of 0.92 with $\mathrm{C}_{4} \mathrm{H}_{9}^{+}(m / z=57)$ and a $r^{2}$ of 0.57 with $\mathrm{NO}_{x}$ (Fig. $\left.2 \mathrm{a}\right)$, indicative of its sources from vehicle emissions ( $\mathrm{Xu}$ et al., 2019a). It is also correlated tightly with BC ( $r^{2}$ of 0.70$)$ and a series of polycyclic aromatic hydrocarbons (PAHs) ions, e.g., $\mathrm{C}_{9} \mathrm{H}_{7}^{+}\left(m / z 115, r^{2}\right.$ of 0.63$)$.

The second factor has a remarkably high fraction of the biomass burning organic aerosol (BBOA) marker ions of $\mathrm{C}_{2} \mathrm{H}_{4} \mathrm{O}_{2}^{+}(m / z=60)(1.31 \%)$ and $\mathrm{C}_{3} \mathrm{H}_{5} \mathrm{O}_{2}^{+}(m / z=73)$ $(1.34 \%)$ in its mass spectrum (Fig. $2 \mathrm{~g}$ ), much higher than that observed in non-BBOA (e.g., $<0.3 \%$ at $m / z=60$ ) in previous studies (Sun et al., 2016; Xu et al., 2019a; Wang et al., 2017). As expected, the temporal variation of this factor is correlated tightly with that of $\mathrm{C}_{2} \mathrm{H}_{4} \mathrm{O}_{2}^{+}$and $\mathrm{C}_{3} \mathrm{H}_{5} \mathrm{O}_{2}^{+}$ ( $r^{2}$ of 0.71 and 0.72 , respectively). In addition, the mass spectrum of this factor is strikingly similar to that of the transported BBOA which was observed at a remote site in the central Tibetan Plateau (Wang et al., 2017), with a $r^{2}$ of 0.97 . Here we categorized the transported BBOA as aged 

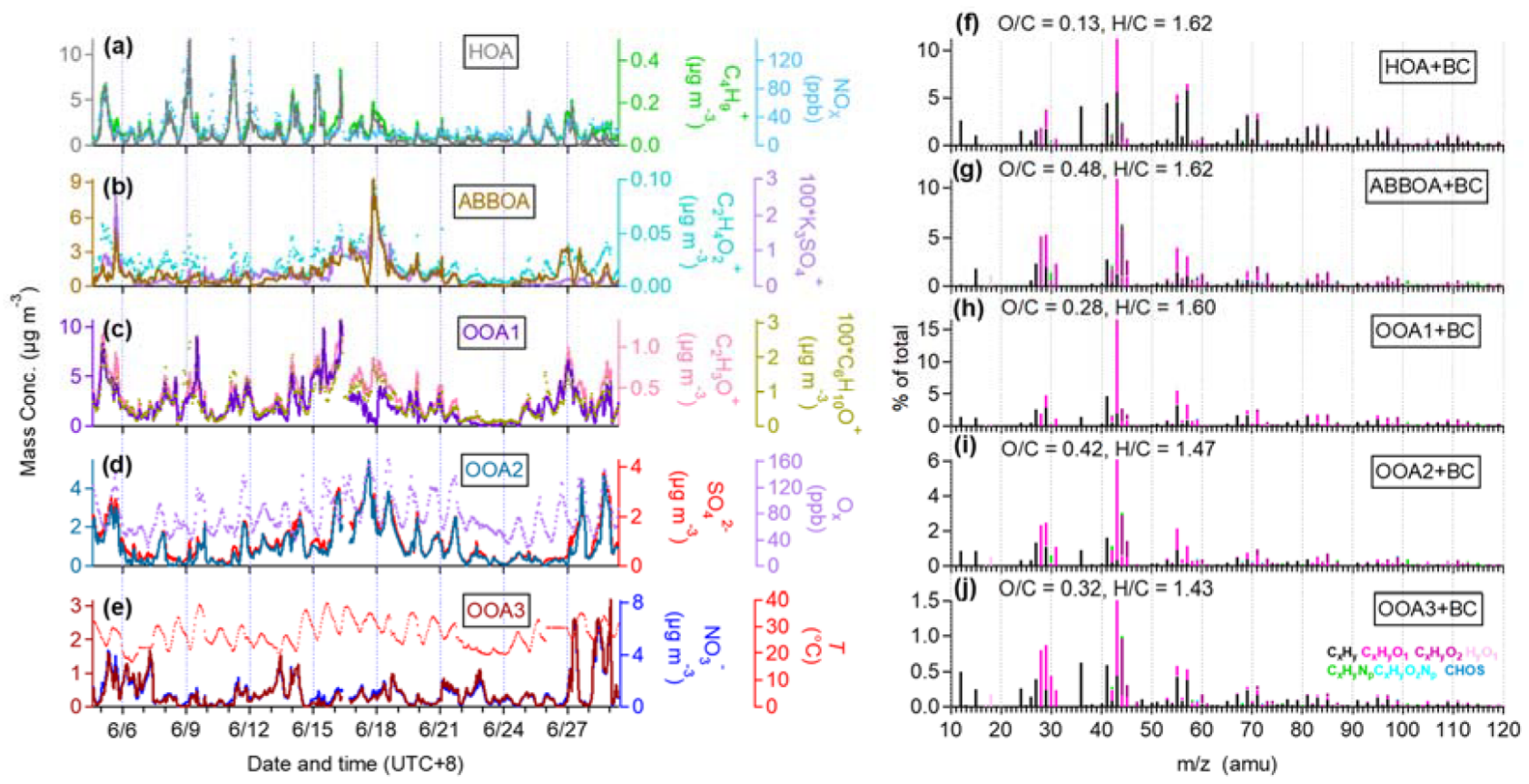

Figure 2. Temporal variations (a-e) and high-resolution mass spectra (f-j) of five OA factors from SP-AMS in summer 2017: (a, f) HOA, $(\mathbf{b}, \mathbf{g})$ A-BBOA, $(\mathbf{c}, \mathbf{h})$ OOA1 (LO-OOA), (d, i) OOA2, and $(\mathbf{e}, \mathbf{j})$ OOA3. Also shown in the left-hand panels are the time series of other tracers, including $\mathrm{C}_{4} \mathrm{H}_{9}^{+}, \mathrm{NO}_{x}, \mathrm{C}_{2} \mathrm{H}_{4} \mathrm{O}_{2}^{+}, \mathrm{K}_{3} \mathrm{SO}_{4}^{+}, \mathrm{C}_{6} \mathrm{H}_{10} \mathrm{O}^{+}, \mathrm{C}_{2} \mathrm{H}_{3} \mathrm{O}^{+}, \mathrm{SO}_{4}^{2-}$, and $\mathrm{NO}_{3}^{-}$.
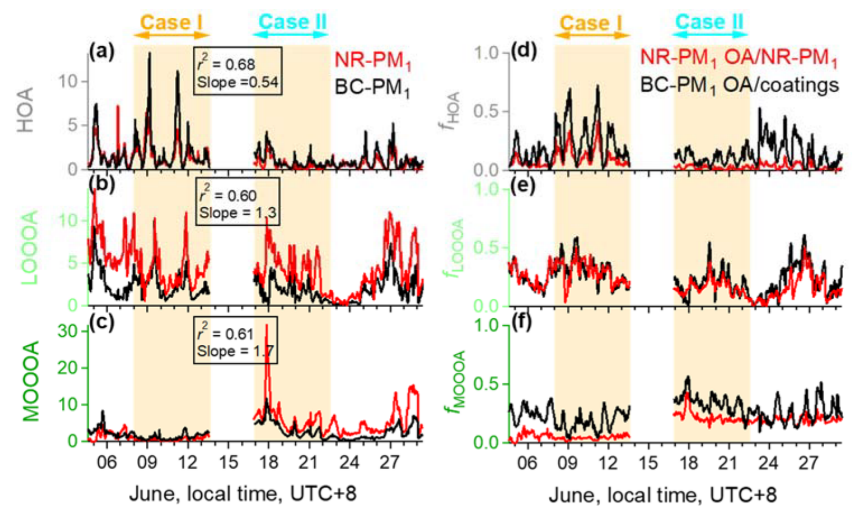

Figure 3. Temporal variations of $\mathrm{NR}-\mathrm{PM}_{1}$ and $\mathrm{BC}-\mathrm{PM}_{1}$ (ac) HOA, LO-OOA, and MO-OOA and (d and e) their fractions. $\mathrm{NR}-\mathrm{PM}_{1} \mathrm{OA}$ factors are in red, and the $\mathrm{BC}-\mathrm{PM}_{1} \mathrm{OA}$ factors are in black. Here $\mathrm{BC}-\mathrm{PM}_{1} \mathrm{MO}-\mathrm{OOA}$ is the sum of A-BBOA, OOA2 (sulfate-related OOA), and OOA3 (nitrate-related OOA).

BBOA (A-BBOA). Similar to the A-BBOA observed in the Tibetan Plateau, which has an $\mathrm{O} / \mathrm{C}$ ratio of 0.51 , this factor also has a relatively high $\mathrm{O} / \mathrm{C}$ ratio of 0.48 , greater than that of primary BBOA $(\mathrm{O} / \mathrm{C}$ of $0.18-0.26)$ (Wang et al., 2017). These findings support the premise that the second factor may be associated with the oxidation of biomass burning emissions. The temporal variation of A-BBOA in the Tibetan Plateau was reported to be highly correlated with the potassium ion fraction $\left(\mathrm{K}^{+}, r^{2}\right.$ of 0.78$)$ and $\mathrm{K}_{3} \mathrm{SO}_{4}^{+}\left(r^{2}\right.$ of 0.92$)$.
However, the temporal variation of the second factor in this study is only correlated well with that of $\mathrm{K}_{3} \mathrm{SO}_{4}^{+}\left(r^{2}\right.$ of 0.64$)$ and not $\mathrm{K}^{+}\left(r^{2}\right.$ of 0.01$)$. The reason for this phenomenon is that the major source of $\mathrm{K}^{+}$in remote sites like the Tibetan Plateau was the long-distance transport of $\mathrm{K}_{2} \mathrm{SO}_{4}$ particles, which are probably generated from biomass-burningrelated K-containing salts with $\mathrm{H}_{2} \mathrm{SO}_{4}$ (Buxton et al., 1999). In contrast, there are multiple primary sources of $\mathrm{K}^{+}$in $\mathrm{PM}_{1}$ (e.g., diesel-vehicle emissions, and mainly $\mathrm{KCl}$ particles) in urban areas (Fig. S3 in the Supplement). Based on these observations, $\mathrm{K}_{3} \mathrm{SO}_{4}^{+}$not $\mathrm{K}^{+}$could be defined as an external A$\mathrm{BBOA}$ indicator. Moreover, a previous transmission electron microscopy study also showed that significant agricultural BBOA was mixed with soot and transported from the North China Plain to urban Beijing; meanwhile, $\mathrm{K}_{2} \mathrm{SO}_{4}$ was also identified within those single BBOA-soot particles ( $\mathrm{Li}$ et al., 2010). Hence, this second factor is identified as A-BBOA that was subjected to oxidation during transport to the measurement area as presented in the fire-point map and $3 \mathrm{~d}$ back trajectories (Fig. S4 in the Supplement). June should be the month with maximum agricultural-related biomass burning in the North China Plain, although we thought that such burning activities had been banned in recent years (Shen et al., 2019).

The OOA 1 factor has an $\mathrm{O} / \mathrm{C}$ of 0.28 (Fig. 2h). Similar to the NR-PM 1 LO-OOA (Xu et al., 2019b), it is highly correlated with $\mathrm{C}_{2} \mathrm{H}_{3} \mathrm{O}^{+}\left(r^{2}\right.$ of 0.72$)$. The $\mathrm{C}_{2} \mathrm{H}_{3} \mathrm{O}^{+}$ion $(m / z=43)$ is an important component of secondary organic 

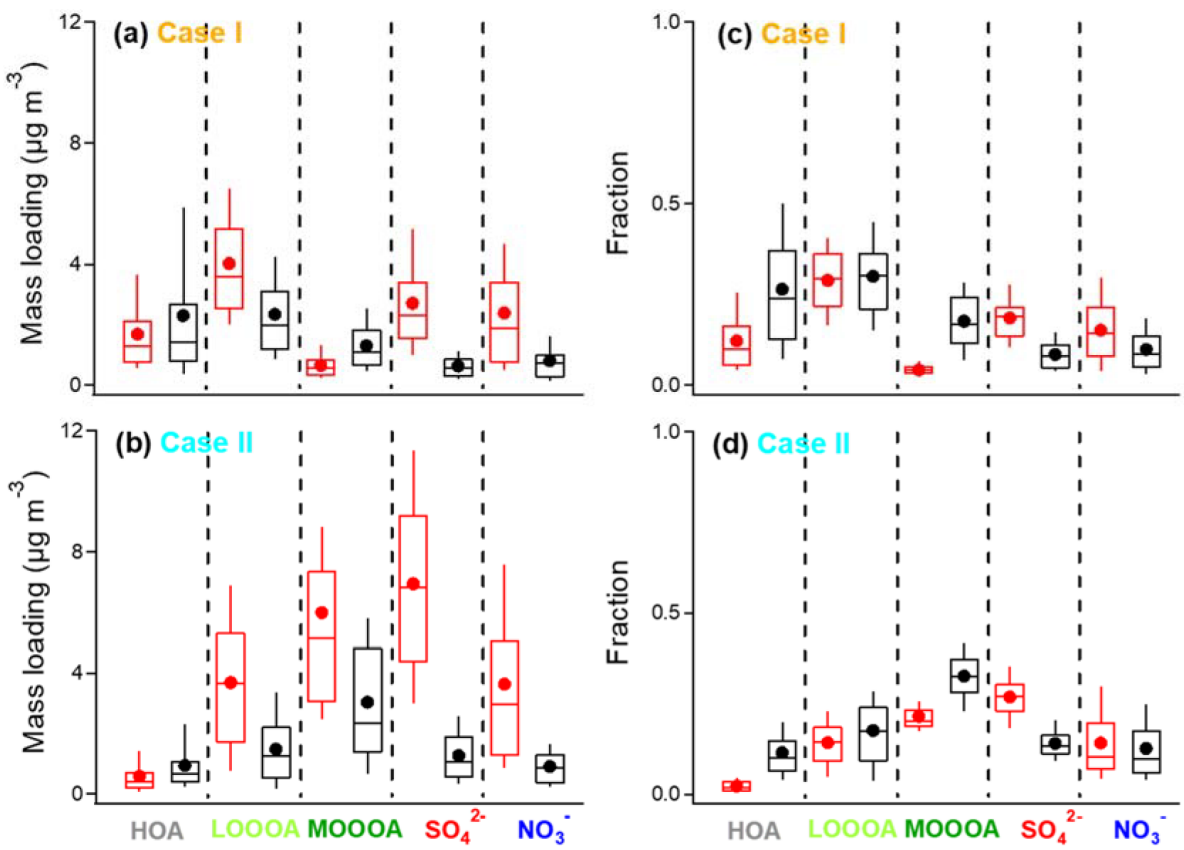

Figure 4. Box plots of mass loadings and fractions of five selected species (HOA, LO-OOA, MO-OOA, $\mathrm{SO}_{4}^{2-}$, and $\mathrm{NO}_{3}^{-}$) in Cases I and II. The bounds of boxes represent quartiles, the whiskers indicate the 90th and 10th percentiles, and the lines and dots inside the boxes are median and mean values. $\mathrm{NR}-\mathrm{PM}_{1} \mathrm{OA}$ factors are in red, and the $\mathrm{BC}-\mathrm{PM}_{1} \mathrm{OA}$ factors are in black.

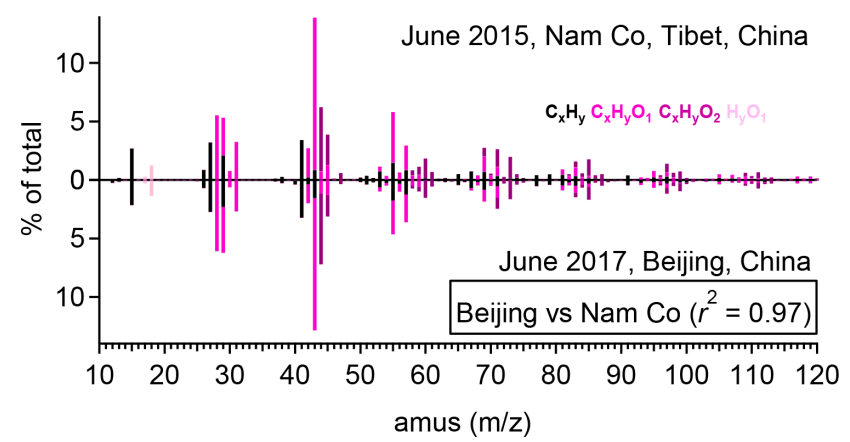

Figure 5. Comparison between the high-resolution mass spectra of A-BBOA obtained in Nam Co (June 2015) and Beijing (June 2017) (nitrogen-containing ions are not shown here).

aerosol (SOA) (Collier et al., 2015; $\mathrm{Ng}$ et al., 2011), and the diurnal patterns of the OOA1 and $\mathrm{C}_{2} \mathrm{H}_{3} \mathrm{O}^{+}$both show a great enhancement around noontime (Fig. S5 in the Supplement), indicating the importance of the secondary formation of lessoxidized organic aerosol through daytime photochemical activity.

The OOA2 factor has an $\mathrm{O} / \mathrm{C}$ of 0.42 (Fig. 2i), and the OOA3 factor has a smaller $\mathrm{O} / \mathrm{C}$ of 0.32 (Fig. 2j). OOA2 is correlated strongly with sulfate $\left(r^{2}\right.$ of 0.92 ; Fig. $\left.2 \mathrm{~d}\right)$, and OOA3 is correlated highly with nitrate ( $r^{2}$ of 0.97 ; Fig. 2e). These features agree well with the previous observation of low-volatility OOA (sulfate-related OOA) and semi-volatile
OOA (nitrate-related OOA) in the Tibetan Plateau (Wang et al., 2017).

\subsection{Comparison of $\mathrm{NR}-\mathrm{PM}_{1}$ and $\mathrm{BC}-\mathrm{PM}_{1} \mathrm{OA}$ factors}

The sum of the above-mentioned $\mathrm{BC}-\mathrm{PM}_{1} \mathrm{~A}-\mathrm{BBOA}$, $\mathrm{OOA} 2$, and OOA3 fractions is comparable to the $\mathrm{NR}-\mathrm{PM}_{1}$ $\mathrm{MO}-\mathrm{OOA}$ factor, based on their high $\mathrm{O} / \mathrm{C}$ ratios. Figure $3 \mathrm{a}-\mathrm{c}$ are comparisons of the mass loadings of HOA, LO-OOA, and MO-OOA in both NR-PM $\mathrm{PM}_{1}$ and $\mathrm{BC}-\mathrm{PM}_{1}$. NR- $-\mathrm{PM}_{1} \mathrm{HOA}$, LO-OOA, and MO-OOA are strongly correlated with their counterpart fractions of $\mathrm{BC}-\mathrm{PM}_{1}$, with $r^{2}$ values of 0.68 , 0.60 , and 0.61 , respectively. In Case I, most of the time, the mass loadings of $\mathrm{BC}-\mathrm{PM}_{1} \mathrm{HOA}$ and $\mathrm{MO}-\mathrm{OOA}$ are higher than those in $\mathrm{NR}-\mathrm{PM}_{1}$, while LO-OOA shows the opposite trend. In Case II, the mass loadings of $\mathrm{BC}-\mathrm{PM}_{1} \mathrm{HOA}$ are also generally higher than those of $\mathrm{NR}-\mathrm{PM}_{1} \mathrm{HOA}$; however, $\mathrm{NR}-\mathrm{PM}_{1}$ MO-OOA and LO-OOA are almost 2-fold higher than those of $\mathrm{BC}-\mathrm{PM}_{1}$. Figure $3 \mathrm{~d}-\mathrm{f}$ are comparisons of the fractions of HOA, LO-OOA, and MO-OOA in NR- $\mathrm{PM}_{1}$ and non- $\mathrm{BC}$ material in $\mathrm{BC}-\mathrm{PM}_{1}$ (coatings), respectively. In Case I, the fractions of HOA and MO-OOA internally mixed with $\mathrm{BC}$ are almost 2 times and 4 times higher, respectively, than those in $\mathrm{NR}-\mathrm{PM}_{1}$, whereas the two LO-OOA fractions closely track each other. In Case II, two LO-OOA fractions are still overlapped, but compared to Case I, the fraction of $\mathrm{HOA}$ in $\mathrm{BC}-\mathrm{PM}_{1}$ coatings is over 4 times that of $\mathrm{NR}-\mathrm{PM}_{1}$ $\mathrm{HOA}$, and the difference between the two MO-OOA fractions is smaller. 

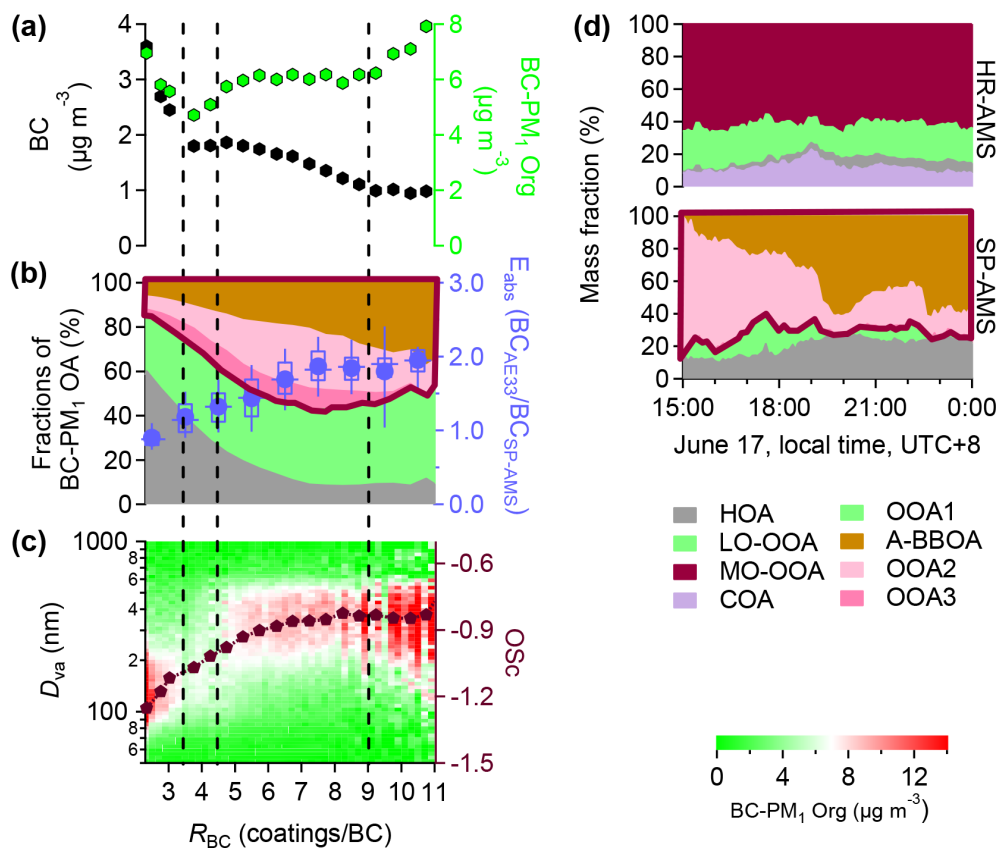

Figure 6. (a-c) The mass loadings of $\mathrm{BC}$ and $\mathrm{BC}-\mathrm{PM}_{1}$ Org, the fractions of $\mathrm{BC}-\mathrm{PM}_{1} \mathrm{OA}$ factors, $E_{\mathrm{abs}}$, the oxidation state $(\mathrm{OSc}=2 \times$ $(\mathrm{O} / \mathrm{C})-(\mathrm{H} / \mathrm{C}))$ of $\mathrm{BC}-\mathrm{PM}_{1}$ Org, and the size distribution of $\mathrm{BC}-\mathrm{PM}_{1}$ Org as a function of coating thickness $\left(R_{\mathrm{BC}}\right)$. $(\mathbf{d})$ Temporal variations of $\mathrm{OA}$ fractions of $\mathrm{NR}-\mathrm{PM}_{1}$ and $\mathrm{BC}-\mathrm{PM}_{1}$ from 15:00 to 24:00 on 17 June 2017.

As shown in Fig. 4, the averages of $\mathrm{BC}-\mathrm{PM}_{1} \mathrm{HOA}$ fractions $(0.27 \pm 0.17$ and $0.11 \pm 0.07$, respectively) are higher than those in $\mathrm{NR}-\mathrm{PM}_{1}(0.12 \pm 0.08$ and $0.02 \pm 0.02$, respectively) in both Case I and Case II, indicating that HOA particles are more internally mixed with $\mathrm{BC}$ compared to other OA materials. However, the possibility that the RIE of OA coating may be lower than the default RIE value should also be considered.

The average mass loadings of $\mathrm{NR}-\mathrm{PM}_{1} \mathrm{LO}-\mathrm{OOA}$ in both Case I and Case II were higher than those of $\mathrm{BC}-\mathrm{PM}_{1}$. However, the fractions of LO-OOA in both $\mathrm{NR}-\mathrm{PM}_{1}$ and $\mathrm{BC}-\mathrm{PM}_{1}$ coatings were very close to each other during the two cases, with an average value of $0.23 \pm 0.10$ and $0.25 \pm 0.12$, respectively, indicating that the probability of LO-OOA condensation onto the two different types of particles is similar.

A greater difference between the MO-OOA fractions in $\mathrm{NR}-\mathrm{PM}_{1}$ and $\mathrm{BC}-\mathrm{PM}_{1}$ was observed in Case I than in Case II, and there is more MO-OOA in $\mathrm{BC}-\mathrm{PM}_{1}$ than in $\mathrm{NR}-\mathrm{PM}_{1}$ in Case I. A similar comparison between $\mathrm{NR}-\mathrm{PM}_{1} \mathrm{MO}-\mathrm{OOA}$ with $\mathrm{BC}-\mathrm{PM}_{1} \mathrm{MO}-\mathrm{OOA}$ without ABBOA can be found in Fig. S6 in the Supplement, which shows closer fractions in both Case I and Case II. Therefore, one possibility that may cause a higher MO-OOA fraction in $\mathrm{BC}-\mathrm{PM}_{1}$ than that in $\mathrm{NR}-\mathrm{PM}_{1}$ in Case $\mathrm{I}$ is the presence of A-BBOA, which is only identified from the $\mathrm{BC}-\mathrm{PM}_{1}$ OA. More details of the $\mathrm{BC}-\mathrm{PM}_{1} \mathrm{~A}-\mathrm{BBOA}$ are discussed in Sect. 3.4.

\subsection{Characteristics of A-BBOA in $\mathrm{BC}-\mathrm{PM}_{1}$}

Figure 5 shows the high-resolution mass spectra of A-BBOA observed in Nam Co (June 2015) and Beijing (June 2017) by laser-only SP-AMS. A mass spectrum very similar to that observed in Beijing was also observed in Nanjing (February 2017) (Wu et al., 2019), with a $r^{2}$ of 0.95 . The A-BBOA observed in Nam Co (the Tibetan Plateau) was found in the thickest coated and internally mixed $\mathrm{BC}-\mathrm{PM}_{1}$ (the mass ratio of coatings to $\mathrm{BC}$ core $\left(R_{\mathrm{BC}}\right)$ can reach 14$)$, which enhances the light absorption ability ( $E_{\text {abs }}$ ) of the BC core by a factor of 1.5 to 2.0 via the lensing effect.

As shown in Fig. 6, A-BBOA was associated with those large particles $\left(D_{\mathrm{va}}>300 \mathrm{~nm}\right)$ which were also heavily coated $\left(R_{\mathrm{BC}}>9\right.$, Fig. $6 \mathrm{a}$ and c). Because A-BBOA is a moderately aged $\mathrm{OA}$, the oxidation state (OSc) was very steady when $R_{\mathrm{BC}}>9$ (Fig. 6c). Figure 6b presents the fractions of the OA factors (left) and the degree of light absorption enhancement ( $E_{\mathrm{abs}}$, estimated by the mass ratios of $\mathrm{BC}$ measured by Aethalometer model 33 and SP-AMS), as a function of $R_{\mathrm{BC}}$. Figure $6 \mathrm{~d}$ shows the temporal variations of the fractions of $\mathrm{NR}-\mathrm{PM}_{1} \mathrm{OA}$ and $\mathrm{BC}-\mathrm{PM}_{1} \mathrm{OA}$ from 15:00 to 24:00 on 17 June 2017 when the highest A-BBOA concentrations were observed. There is a significant enhancement of A-BBOA which may account for up to $60 \%$ of the total OA coatings, which could enhance the $\mathrm{BC}-\mathrm{PM}_{1} \mathrm{MO}-\mathrm{OOA}$ fraction (within the dark red frame in the bottom panel of Fig. 6d). 
In this study, A-BBOA was only observed by SP-AMS and was indeed only associated with BC. It is likely that ABBOA was emitted together with $\mathrm{BC}$ when burning biomass fuel and was oxidized subsequently during transport. However, we cannot exclude the possibility that A-BBOA can be detected by HR-AMS. For example, it might be included in the NR- $\mathrm{PM}_{1}$ MO-OOA factor. Without separating ABBOA from other organic species, the source apportionment for HR-AMS may obscure air-quality- and climate-related implications of A-BBOA in the atmosphere, such as the enhancement of the aerosol light absorption ability (Fig. 6b).

\section{Conclusions and implications}

Online chemical characteristics of $\mathrm{BC}$ and its associated species were for the first time elucidated in urban Beijing in summer and compared with those of $\mathrm{NR}-\mathrm{PM}_{1}$ species. The biggest difference between the two measurements was in the composition of the organic species. In particular, we found $\mathrm{BC}$ in urban Beijing in June is partially of agricultural fire origin and that a unique biomass-burning-related OA factor (A-BBOA), which was moderately aged, only existed in thickly coated $\mathrm{BC}-\mathrm{PM}_{1}\left(R_{\mathrm{BC}}>9\right)$ and not $\mathrm{NR}-\mathrm{PM}_{1}$. The unique A-BBOA could make up a significant portion of $\mathrm{BC}$ coating material. In addition to Beijing, similar ABBOA was also identified in other locations, such as the central Tibetan Plateau (Wang et al., 2017) and Nanjing (Wu et al., 2019), suggesting that it may be ubiquitously present in $\mathrm{BC}-\mathrm{PM}_{1}$ in the ambient atmosphere.
BBOA species are known to constitute a large portion of light-absorbing organics (brown carbon, $\mathrm{BrC}$ ). The delay of $\mathrm{BBOA}$ oxidation and its longer duration time on $\mathrm{BC}$ cores can extend the impacts of $\mathrm{BC}$. Moreover, together with our previous study of BC-associated A-BBOA in Tibet, results presented herein demonstrate that A-BBOA could lead to thick coating on $\mathrm{BC}$ cores, meaning a significant lensing effect on the enhancement of BC light absorption (Liu et al., 2017). As a key component of $B C$ coating, presence of this factor may also alter the bulk hygroscopicity of $\mathrm{BC}-\mathrm{PM}_{1}$. It could therefore affect its ability as cloud condensation nuclei (CCN) (Wu et al., 2019). Overall, the emission, evolution, and transport of such A-BBOA may influence the atmospheric behaviors and the role of $\mathrm{BC}$ in air quality and the climate (e.g., radiative forcing and precipitation). We propose that future laboratory, field, and modeling studies are needed to verify the presence of A-BBOA and to evaluate the regional environmental impacts of it. 


\section{Appendix A: Abbreviations}

$\begin{array}{ll}\mathrm{BC} & \text { Black carbon } \\ \mathrm{PM}_{1} & \text { Particulate matter with an aerodynamic diameter smaller than 1 } \mu \mathrm{m} \\ \mathrm{NR}_{1}-\mathrm{PM}_{1} & \text { Non-refractory } \mathrm{PM}_{1} \\ \mathrm{BC}-\mathrm{PM}_{1} & \text { BC-containing particles in } \mathrm{PM}_{1} \\ \mathrm{BrC} & \text { Brown carbon } \\ \text { HR-AMS } & \text { High-resolution aerosol mass spectrometer (Aerodyne Research Inc.) } \\ \text { SP-AMS } & \text { Soot-particle aerosol mass spectrometer (Aerodyne Research Inc.) } \\ \text { IE } & \text { Ionization efficiency } \\ \text { RIE } & \text { Relative ionization efficiency } \\ \text { HRMS } & \text { High-resolution mass spectra } \\ \mathrm{PMF} & \text { Positive matrix factorization } \\ \mathrm{OA} & \text { Organic aerosol } \\ \text { SOA } & \text { Secondary organic aerosol } \\ \mathrm{O} / \mathrm{C} & \text { Oxygen-to-carbon ratio } \\ \mathrm{H} / \mathrm{C} & \text { Hydrogen-to-carbon ratio } \\ \mathrm{A}-\mathrm{BBOA} & \text { Aged biomass burning organic aerosol } \\ \text { SV-OOA } & \text { Semi-volatile oxygenated organic aerosol } \\ \text { LV-OOA } & \text { Low-volatility oxygenated organic aerosol } \\ \text { MO-OOA } & \text { More-oxidized oxygenated organic aerosol } \\ \text { LO-OOA } & \text { Less-oxidized oxygenated organic aerosol } \\ R_{\mathrm{BC}} & \text { Mass ratio of BC coatings to BC } \\ D_{\text {va }} & \text { Vacuum aerodynamic diameter }\end{array}$


Code and data availability. The data in this study are available from the authors upon request (caxinra@163.com or wangjunfeng@seas.harvard.edu).

Supplement. The supplement related to this article is available online at: https://doi.org/10.5194/acp-20-14091-2020-supplement.

Author contributions. JW, DL, YW, JZ, WX, CX, FS, and XG conducted the measurements and analyzed the data. JW, JY, and PO wrote the first draft of the paper. JZ, PO, YQ, XZ, AL, SM, PF, DJ, QZ, YS, MC, and XG contributed to the analyses and improvement of the paper. JW and $\mathrm{XG}$ contributed to the revision of the paper.

Competing interests. The authors declare that they have no conflict of interest.

Special issue statement. This article is part of the special issue "In-depth study of air pollution sources and processes within Beijing and its surrounding region (APHH-Beijing) (ACP/AMT interjournal SI)". It is not associated with a conference.

Acknowledgements. The authors from PRC acknowledge support from the National Natural Science Foundation of China (21777073) and the National Key Research and Development Program of China (no. 2018YFC0213802). The authors from Harvard and NUIST acknowledge additional support through the Harvard-NUIST Joint Laboratory for Air Quality and Climate (JLAQC).

Financial support. This research has been supported by the National Natural Science Foundation of China (grant no. 21777073), the National Key Research and Development Program of China (grant no. 2018YFC0213802), and the Harvard-NUIST Joint Laboratory for Air Quality and Climate (JLAQC).

Review statement. This paper was edited by Yongjie Li and reviewed by two anonymous referees.

\section{References}

Bond, T. C., Doherty, S. J., Fahey, D. W., Forster, P. M., Berntsen, T., DeAngelo, B. J., Flanner, M. G., Ghan, S., Kärcher, B., Koch, D., Kinne, S., Kondo, Y., Quinn, P. K., Sarofim, M. C., Schultz, M. G., Schulz, M., Venkataraman, C., Zhang, H., Zhang, S., Bellouin, N., Guttikunda, S. K., Hopke, P. K., Jacobson, M. Z., Kaiser, J. W., Klimont, Z., Lohmann, U., Schwarz, J. P., Shindell, D., Storelvmo, T., Warren, S. G., and Zender, C. S.: Bounding the role of black carbon in the climate system: A scientific assessment, J. Geophys. Res.-Atmos, 118, 5380-5552, https://doi.org/10.1002/jgrd.50171, 2013.
Buseck, P. R., Adachi, K., Gelencsér, A., Tompa, É., and Pósfai, M.: Ns-Soot: A Material-Based Term for Strongly LightAbsorbing Carbonaceous Particles, Aerosol Sci. Tech., 48, 777788, https://doi.org/10.1080/02786826.2014.919374, 2014.

Buxton, G. V., Bydder, M., and Arthur Salmon, G.: The reactivity of chlorine atoms in aqueous solution. Part II. The equilibrium $\mathrm{SO}_{4}^{-}+\mathrm{Cl}^{-} \mathrm{Cl}^{\mathrm{Nsbd}}+\mathrm{SO}_{4}^{2-}$, Phys. Chem. Chem. Phys., 1, 269273, https://doi.org/10.1039/A807808D, 1999.

Canagaratna, M. R., Jayne, J. T., Jimenez, J. L., Allan, J. D., Alfarra, M. R., Zhang, Q., Onasch, T. B., Drewnick, F., Coe, H., Middlebrook, A., Delia, A., Williams, L. R., Trimborn, A. M., Northway, M. J., DeCarlo, P. F., Kolb, C. E., Davidovits, P., and Worsnop, D. R.: Chemical and microphysical characterization of ambient aerosols with the aerodyne aerosol mass spectrometer, Mass Spectrom. Rev., 26, 185-222, https://doi.org/10.1002/Mas.20115, 2007.

Canagaratna, M. R., Jimenez, J. L., Kroll, J. H., Chen, Q., Kessler, S. H., Massoli, P., Hildebrandt Ruiz, L., Fortner, E., Williams, L. R., Wilson, K. R., Surratt, J. D., Donahue, N. M., Jayne, J. T., and Worsnop, D. R.: Elemental ratio measurements of organic compounds using aerosol mass spectrometry: characterization, improved calibration, and implications, Atmos. Chem. Phys., 15, 253-272, https://doi.org/10.5194/acp-15-253-2015, 2015a.

Canagaratna, M. R., Massoli, P., Browne, E. C., Franklin, J. P., Wilson, K. R., Onasch, T. B., Kirchstetter, T. W., Fortner, E. C., Kolb, C. E., Jayne, J. T., Kroll, J. H., and Worsnop, D. R.: Chemical Compositions of Black Carbon Particle Cores and Coatings via Soot Particle Aerosol Mass Spectrometry with Photoionization and Electron Ionization, J. Phys. Chem. A, 119, 4589-4599, https://doi.org/10.1021/jp510711u, 2015b.

Cappa, C. D., Onasch, T. B., Massoli, P., Worsnop, D. R., Bates, T. S., Cross, E. S., Davidovits, P., Hakala, J., Hayden, K. L., Jobson, B. T., Kolesar, K. R., Lack, D. A., Lerner, B. M., Li, S.-M., Mellon, D., Nuaaman, I., Olfert, J. S., Petäjä, T., Quinn, P. K., Song, C., Subramanian, R., Williams, E. J., and Zaveri, R. A.: Radiative absorption enhancements due to the mixing state of atmospheric black carbon, Science, 337, 1078-1081, https://doi.org/10.1126/science.1223447, 2012.

Chen, B., Andersson, A., Lee, M., Kirillova, E. N., Xiao, Q., Kruså, M., Shi, M., Hu, K., Lu, Z., Streets, D. G., Du, K., and Gustafsson, Ö.: Source Forensics of Black Carbon Aerosols from China, Environ. Sci. Technol., 47, 9102-9108, https://doi.org/10.1021/es401599r, 2013.

Chen, Y., Cai, J., Wang, Z., Peng, C., Yao, X., Tian, M., Han, Y., Shi, G., Shi, Z., Liu, Y., Yang, X., Zheng, M., Zhu, T., He, K., Zhang, Q., and Yang, F.: Simultaneous measurements of urban and rural particles in Beijing - Part 1: Chemical composition and mixing state, Atmos. Chem. Phys., 20, 9231-9247, https://doi.org/10.5194/acp-20-9231-2020, 2020a.

Chen, Y., Shi, G., Cai, J., Shi, Z., Wang, Z., Yao, X., Tian, M., Peng, C., Han, Y., Zhu, T., Liu, Y., Yang, X., Zheng, M., Yang, F., Zhang, Q., and He, K.: Simultaneous measurements of urban and rural particles in Beijing - Part 2: Case studies of haze events and regional transport, Atmos. Chem. Phys., 20, 92499263, https://doi.org/10.5194/acp-20-9249-2020, 2020b.

China, S., Scarnato, B., Owen, R. C., Zhang, B., Ampadu, M. T., Kumar, S., Dzepina, K., Dziobak, M. P., Fialho, P., Perlinger, J. A., Hueber, J., Helmig, D., Mazzoleni, L. R., and Mazzoleni, C.: Morphology and mixing state of aged soot par- 
ticles at a remote marine free troposphere site: Implications for optical properties, Geophys. Res. Lett., 42, 1243-1250, https://doi.org/10.1002/2014g1062404, 2015.

Collier, S., Zhou, S., Kuwayama, T., Forestieri, S., Brady, J., Zhang, M., Kleeman, M., Cappa, C., Bertram, T., and Zhang, Q.: Organic PM Emissions from Vehicles: Composition, O/C Ratio, and Dependence on PM Concentration, Aerosol Sci. Tech., 49, 86-97, https://doi.org/10.1080/02786826.2014.1003364, 2015.

Ge, X., Zhang, Q., Sun, Y., Ruehl, C. R., and Setyan, A.: Effect of aqueous-phase processing on aerosol chemistry and size distributions in Fresno, California, during wintertime, Environ. Chem., 9, 221-235, https://doi.org/10.1071/EN11168, 2012a.

Ge, X. L., Setyan, A., Sun, Y., and Zhang, Q.: Primary and secondary organic aerosols in Fresno, California during wintertime: Results from high resolution aerosol mass spectrometry, J. Geophys. Res.-Atmos., 117, D19301, https://doi.org/10.1029/2012jd018026, 2012b.

Janssen, N. A. H., Gerlofs-Nijland, M., Lanki, T., Salonen, R. O., Cassee, F., Hoek, G., Fischer, P., Brunekreef, B., and Krzyzanowski, M.: Health effects of black carbon, available at: https://www.euro.who.int/_data/assets/pdf_file/0004/ 162535/e96541.pdf?ua=1 (last access: 16 November 2020), WHO, 2012.

Lee, A. K. Y., Chen, C.-L., Liu, J., Price, D. J., Betha, R., Russell, L. M., Zhang, X., and Cappa, C. D.: Formation of secondary organic aerosol coating on black carbon particles near vehicular emissions, Atmos. Chem. Phys., 17, 15055-15067, https://doi.org/10.5194/acp-17-15055-2017, 2017.

Lee, B. P., Li, Y. J., Yu, J. Z., Louie, P. K. K., and Chan, C. K.: Physical and chemical characterization of ambient aerosol by HR-ToF-AMS at a suburban site in Hong Kong during springtime 2011, J. Geophys. Res.-Atmos., 118, 8625-8639, https://doi.org/10.1002/jgrd.50658, 2013.

Li, W. J., Shao, L. Y., and Buseck, P. R.: Haze types in Beijing and the influence of agricultural biomass burning, Atmos. Chem. Phys., 10, 8119-8130, https://doi.org/10.5194/acp-108119-2010, 2010.

Li, Y. J., Lee, B. P., Su, L., Fung, J. C. H., and Chan, C. K.: Seasonal characteristics of fine particulate matter (PM) based on highresolution time-of-flight aerosol mass spectrometric (HR-ToFAMS) measurements at the HKUST Supersite in Hong Kong, Atmos. Chem. Phys., 15, 37-53, https://doi.org/10.5194/acp-1537-2015, 2015.

Liu, C., Chung, C. E., Yin, Y., and Schnaiter, M.: The absorption Ångström exponent of black carbon: from numerical aspects, Atmos. Chem. Phys., 18, 6259-6273, https://doi.org/10.5194/acp18-6259-2018, 2018.

Liu, D., Whitehead, J., Alfarra, M. R., Reyes-Villegas, E., Spracklen, Dominick V., Reddington, Carly L., Kong, S., Williams, Paul I., Ting, Y.-C., Haslett, S., Taylor, Jonathan W., Flynn, Michael J., Morgan, William T., McFiggans, G., Coe, H., and Allan, and James D.: Black-carbon absorption enhancement in the atmosphere determined by particle mixing state, Nat. Geosci., 10, 184-188, https://doi.org/10.1038/ngeo2901, 2017.

Liu, D., Joshi, R., Wang, J., Yu, C., Allan, J. D., Coe, H., Flynn, M. J., Xie, C., Lee, J., Squires, F., Kotthaus, S., Grimmond, S., Ge, X., Sun, Y., and Fu, P.: Contrasting physical properties of black carbon in urban Beijing between winter and summer, At- mos. Chem. Phys., 19, 6749-6769, https://doi.org/10.5194/acp19-6749-2019, 2019.

Massoli, P., Onasch, T. B., Cappa, C. D., Nuamaan, I., Hakala, J., Hayden, K., Li, S.-M., Sueper, D. T., Bates, T. S., Quinn, P. K., Jayne, J. T., and Worsnop, D. R.: Characterization of black carbon-containing particles from soot particle aerosol mass spectrometer measurements on the R/V Atlantis during CalNex 2010, J. Geophys. Res.-Atmos., 120, https://doi.org/10.1002/2014JD022834, 2015.

Ng, N. L., Canagaratna, M. R., Jimenez, J. L., Chhabra, P. S., Seinfeld, J. H., and Worsnop, D. R.: Changes in organic aerosol composition with aging inferred from aerosol mass spectra, Atmos. Chem. Phys., 11, 6465-6474, https://doi.org/10.5194/acp11-6465-2011, 2011.

Onasch, T. B., Trimborn, A., Fortner, E. C., Jayne, J. T., Kok, G. L., Williams, L. R., Davidovits, P., and Worsnop, D. R.: Soot Particle Aerosol Mass Spectrometer: Development, Validation, and Initial Application, Aerosol Sci. Techn., 46, 804-817, https://doi.org/10.1080/02786826.2012.663948, 2012.

Paatero, P. and Tapper, U.: Positive matrix factorization: A non-negative factor model with optimal utilization of error estimates of data values, Environmetrics, 5, 111-126, https://doi.org/10.1002/env.3170050203, 1994.

Qiu, Y., Xie, Q., Wang, J., Xu, W., Li, L., Wang, Q., Zhao, J., Chen, Y., Chen, Y., Wu, Y., Du, W., Zhou, W., Lee, J., Zhao, C., Ge, X., Fu, P., Wang, Z., Worsnop, D. R., and Sun, Y.: Vertical Characterization and Source Apportionment of Water-Soluble Organic Aerosol with High-resolution Aerosol Mass Spectrometry in Beijing, China, ACS Earth Space Chem., 3, 273-284, https://doi.org/10.1021/acsearthspacechem.8b00155, 2019.

Ramanathan, V. and Carmichael, G.: Global and regional climate changes due to black carbon, Nat. Geosci., 1, 221-227, 2008.

Saleh, R., Marks, M., Heo, J., Adams, P. J., Donahue, N. M., and Robinson, A. L.: Contribution of brown carbon and lensing to the direct radiative effect of carbonaceous aerosols from biomass and biofuel burning emissions, J. Geophys. Res.-Atmos., 120, 10285-10296, https://doi.org/10.1002/2015jd023697, 2015.

Shen, L., Jacob, D. J., Zhu, L., Zhang, Q., Zheng, B., Sulprizio, M. P., Li, K., De Smedt, I., González Abad, G., Cao, H., Fu, T.-M., and Liao, H.: The 2005-2016 Trends of Formaldehyde Columns Over China Observed by Satellites: Increasing Anthropogenic Emissions of Volatile Organic Compounds and Decreasing Agricultural Fire Emissions, Geophys. Res. Lett., 46, 44684475, https://doi.org/10.1029/2019gl082172, 2019.

Shi, Z., Vu, T., Kotthaus, S., Harrison, R. M., Grimmond, S., Yue, S., Zhu, T., Lee, J., Han, Y., Demuzere, M., Dunmore, R. E., Ren, L., Liu, D., Wang, Y., Wild, O., Allan, J., Acton, W. J., Barlow, J., Barratt, B., Beddows, D., Bloss, W. J., Calzolai, G., Carruthers, D., Carslaw, D. C., Chan, Q., Chatzidiakou, L., Chen, Y., Crilley, L., Coe, H., Dai, T., Doherty, R., Duan, F., Fu, P., Ge, B., Ge, M., Guan, D., Hamilton, J. F., He, K., Heal, M., Heard, D., Hewitt, C. N., Hollaway, M., Hu, M., Ji, D., Jiang, X., Jones, R., Kalberer, M., Kelly, F. J., Kramer, L., Langford, B., Lin, C., Lewis, A. C., Li, J., Li, W., Liu, H., Liu, J., Loh, M., Lu, K., Lucarelli, F., Mann, G., McFiggans, G., Miller, M. R., Mills, G., Monk, P., Nemitz, E., O’Connor, F., Ouyang, B., Palmer, P. I., Percival, C., Popoola, O., Reeves, C., Rickard, A. R., Shao, L., Shi, G., Spracklen, D., Stevenson, D., Sun, Y., Sun, Z., Tao, S., Tong, S., Wang, Q., Wang, W., Wang, X., Wang, X., Wang, Z., 
Wei, L., Whalley, L., Wu, X., Wu, Z., Xie, P., Yang, F., Zhang, Q., Zhang, Y., Zhang, Y., and Zheng, M.: Introduction to the special issue "In-depth study of air pollution sources and processes within Beijing and its surrounding region (APHH-Beijing)", Atmos. Chem. Phys., 19, 7519-7546, https://doi.org/10.5194/acp19-7519-2019, 2019.

Sun, Y., Jiang, Q., Wang, Z., Fu, P., Li, J., Yang, T., and Yin, Y.: Investigation of the Sources and Evolution Processes of Severe Haze Pollution in Beijing in January 2013, J. Geophys. Res.-Atmos., 119, 4380-4398, https://doi.org/10.1002/2014JD021641, 2014.

Sun, Y., Jiang, Q., Xu, Y., Ma, Y., Zhang, Y., Liu, X., Li, W., Wang, F., Li, J., Wang, P., and Li, Z.: Aerosol characterization over the North China Plain: Haze life cycle and biomass burning impacts in summer, J. Geophys. Res.-Atmos., 121, 2508-2521, https://doi.org/10.1002/2015jd024261, 2016.

Sun, Y. L., Zhang, Q., Schwab, J. J., Chen, W.-N., Bae, M.-S., Hung, H.-M., Lin, Y.-C., Ng, N. L., Jayne, J., Massoli, P., Williams, L. R., and Demerjian, K. L.: Characterization of near-highway submicron aerosols in New York City with a high-resolution aerosol mass spectrometer, Atmos. Chem. Phys., 12, 2215-2227, https://doi.org/10.5194/acp-12-2215-2012, 2012.

Ulbrich, I. M., Canagaratna, M. R., Zhang, Q., Worsnop, D. R., and Jimenez, J. L.: Interpretation of organic components from Positive Matrix Factorization of aerosol mass spectrometric data, Atmos. Chem. Phys., 9, 2891-2918, https://doi.org/10.5194/acp-92891-2009, 2009.

Wang, J., Onasch, T. B., Ge, X., Collier, S., Zhang, Q., Sun, Y., Yu, H., Chen, M., Prévôt, A. S., and Worsnop, D. R.: Observation of fullerene soot in eastern China, Environ. Sci. Tech. Let., 3, 121-126, https://doi.org/10.1021/acs.estlett.6b00044, 2016.

Wang, J., Zhang, Q., Chen, M., Collier, S., Zhou, S., Ge, X., Xu, J., Shi, J., Xie, C., and Hu, J.: First chemical characterization of refractory black carbon aerosols and associated coatings over the Tibetan Plateau (4730 ma.s.1.), Environ. Sci. Technol., 51, 14072-14082, https://doi.org/10.1021/acs.est.7b03973, 2017.

Wang, J., Liu, D., Ge, X., Wu, Y., Shen, F., Chen, M., Zhao, J., Xie, C., Wang, Q., Xu, W., Zhang, J., Hu, J., Allan, J., Joshi, R., Fu, P., Coe, H., and Sun, Y.: Characterization of black carboncontaining fine particles in Beijing during wintertime, Atmos. Chem. Phys., 19, 447-458, https://doi.org/10.5194/acp-19-4472019, 2019.
Willis, M. D., Lee, A. K. Y., Onasch, T. B., Fortner, E. C., Williams, L. R., Lambe, A. T., Worsnop, D. R., and Abbatt, J. P. D.: Collection efficiency of the soot-particle aerosol mass spectrometer (SP-AMS) for internally mixed particulate black carbon, Atmos. Meas. Tech., 7, 4507-4516, https://doi.org/10.5194/amt-7-45072014, 2014.

Wu, Y., Liu, D., Wang, J., Shen, F., Chen, Y., Cui, S., Ge, S., Wu, Y., Chen, M., and Ge, X.: Characterization of SizeResolved Hygroscopicity of Black Carbon-Containing Particle in Urban Environment, Environ. Sci. Technol., 53, 14212-14221, https://doi.org/10.1021/acs.est.9b05546, 2019.

Xie, C., Xu, W., Wang, J., Liu, D., Ge, X., Zhang, Q., Wang, Q., Du, W., Zhao, J., Zhou, W., Li, J., Fu, P., Wang, Z., Worsnop, D., and Sun, Y.: Light absorption enhancement of black carbon in urban Beijing in summer, Atmos. Environ., 213, 499-504, https://doi.org/10.1016/j.atmosenv.2019.06.041, 2019a.

Xie, C., Xu, W., Wang, J., Wang, Q., Liu, D., Tang, G., Chen, P., Du, W., Zhao, J., Zhang, Y., Zhou, W., Han, T., Bian, Q., Li, J., Fu, P., Wang, Z., Ge, X., Allan, J., Coe, H., and Sun, Y.: Vertical characterization of aerosol optical properties and brown carbon in winter in urban Beijing, China, Atmos. Chem. Phys., 19, 165179, https://doi.org/10.5194/acp-19-165-2019, 2019b.

Xu, J., Zhang, Q., Shi, J., Ge, X., Xie, C., Wang, J., Kang, S., Zhang, R., and Wang, Y.: Chemical characteristics of submicron particles at the central Tibetan Plateau: insights from aerosol mass spectrometry, Atmos. Chem. Phys., 18, 427-443, https://doi.org/10.5194/acp-18-427-2018, 2018.

Xu, W., Sun, Y., Wang, Q., Zhao, J., Wang, J., Ge, X., Xie, C., Zhou, W., Du, W., and Li, J.: Changes in aerosol chemistry from 2014 to 2016 in winter in Beijing: Insights from high-resolution aerosol mass spectrometry, J. Geophys. Res.-Atmos., 124, 1132-1147, https://doi.org/10.1029/2018JD029245, 2019a.

Xu, W., Xie, C., Karnezi, E., Zhang, Q., Wang, J., Pandis, S. N., Ge, X., Zhang, J., An, J., Wang, Q., Zhao, J., Du, W., Qiu, Y., Zhou, W., He, Y., Li, Y., Li, J., Fu, P., Wang, Z., Worsnop, D. R., and Sun, Y.: Summertime aerosol volatility measurements in Beijing, China, Atmos. Chem. Phys., 19, 10205-10216, https://doi.org/10.5194/acp-19-10205-2019, 2019b.

Zhang, Q., Jimenez, J., Canagaratna, M., Ulbrich, I., Ng, N., Worsnop, D., and Sun, Y.: Understanding atmospheric organic aerosols via factor analysis of aerosol mass spectrometry: a review, Anal. Bioanal. Chem., 401, 3045-3067, https://doi.org/10.1007/s00216-011-5355-y, 2011. 